UDK; 316.344.233

Izvorni znanstveni članak

Primljen 14. X. 2019.

IRENA MUSA

Filozofski fakultet Sveučilišta u Mostaru

irena.musa@ff.sum.ba

\title{
DRUŠTVENE NEJEDNAKOSTI I SIROMAŠTVO
}

\section{Sažetak}

Živimo u razdoblju visokoga i brzoga tehničkog i tehnološkog napretka, razdoblju u kojem su ljudske sudbine opterećene novim iskušenjima i novim izazovima, razdoblju u kojem je djelovanje silnica globalizacijskih procesa umnogostručilo pojedince i ljudske skupine koji su iz središta društvenoga života gurnuti na njegove margine. $S$ „prodorom u novo" osobito se teško nose siromašne zemlje i zemlje u razvoju, $u$ kojima sve više ljudi živi na rubu egzistencije gušeći se u bijedi koja ih ostavlja bez nade i ljudskoga dostojanstva. Bogatstvo i dobitci što ih donose nove tehnologije neravnomjerno su raspodijeljeni u svijetu. $S$ jedne strane stvoren je spektakularno bogat svijet, a s druge strane stvoren je zabrinjavajuće osiromašen svijet $u$ kojem dominira strašno siromaštvo i užasna neimaština. $U$ tome kontekstu u radu se tematizira fenomen vertikalne društvene nejednakosti, siromaštvo i društvena isključenost, s posebnim osvrtom na bosanskohercegovačku suvremenu zbilju u kojoj su oživotvoreni ti fenomeni.

Ključne riječi: društvena stratifikacija; društvena klasa; društveni sloj; siromaštvo; društvena isključenost; Bosna i Hercegovina

\section{Uvod}

Nekada su društveni teoretičari sanjali o društvu u kojem bi nestale podjele na bogate i siromašne, $u$ kojem bi nestale podjele na one koji 
imaju moć i one koji su joj podložni. Međutim, sva dosadašnja iskustva potvrđuju da u svim poznatim ljudskim društvima postoji neki oblik nejednakosti.

U prvome poglavlju ovoga rada riječ je o posebnome obliku društvene nejednakosti, društvenoj stratifikaciji, dakle, vertikalnoj društvenoj nejednakosti koja je utemeljena na nejednakoj raspodjeli rijetkih društvenih vrijednosti i dobara, što dovodi do toga da je različite društvene skupine moguće rangirati na više i niže, odnosno dovodi do procesa oblikovanja i reprodukcije strukturiranih društvenih jedinica odnosno društvenih slojeva. Kako u svakome slojevitom društvu postoje ideje kojima se objašnjava nejednaka raspodjela društvenoga bogatstva, ugleda i moći, u tome kontekstu ističu se neke od njih, a napose originalan pristup američkoga sociologa Pitirima Sorokina. U daljem dijelu teksta pokušava se odgovoriti na pitanje: „Jesu li društvene klase nestale?" Naime, dok se društvene nejednakosti danas ponovno uspostavljaju i produbljuju, postojanje društvenih klasa nije nikada bilo predmet tolikoga osporavanja, do te mjere da je riječ "društvena klasa“ gotovo postala tabu. Daleko smo mi od besklasnoga društva. Neslojevito društvo mit je koji u povijesti čovječanstva nikada nije ostvaren jer stratifikacijski oblici i proporcije variraju, ali njezina bit postoji svugdje i u svim vremenima. U drugome poglavlju tematizira se siromaštvo kao izravna posljedica društvene nejednakosti. Porast siromaštva u svijetu, osobito dugotrajnoga siromaštva koje postaje stalan način života, danas predstavlja veliki problem u mnogim zemljama svijeta. Siromašni ljudi nalaze se na dnu društvene hijerarhije. Siromaštvo i glad guraju ljude u ropski položaj i na društvene margine, što ih ostavlja bez mogućnosti da preuzmu kontrolu nad vlastitim životom. U trećem poglavlju napravljen je osvrt na društvene nejednakosti i siromaštvo u Bosni i Hercegovini.

\section{Društvene razlike i nejednakosti}

Oni koji čitaju knjige, a i oni koji ih pišu nisu, po pravilu, bliže upoznati ni sa krugovima koji čine vrhove, a ni sa onima koji čine dno suvremenog društva; u prisnijoj smo vezi sa srednjim slojevima. Da bismo razumjeli 
srednje društvene slojeve trebamo samo osmotriti ono što se oko nas stvarno zbiva, ali da bismo bili u stanju razumjeti one najviše slojeve, kao i one najniže, moramo najprije nastojati stvari otkriti i opisati ih. Međutim, to je vrlo teško učiniti jer su oni najviši društveni slojevi često nepristupačni, a oni najniži često skriveni. ${ }^{1}$

Nekada su društveni teoretičari sanjali o društvu apsolutne jednakosti. Sve teorije utemeljene na tome načelu polaze od zahtjeva za stvaranjem društva u kojem neće biti istovremeno statusa koji izazivaju divljenje i onih koji znače materijalnu bijedu i poniženje. Takva učenja u sociološkoj literaturi nazvana su utopijama ${ }^{2}$. Pokušaji ostvarenja ideja toga tipa mogu se naći u povijesti, a ima ih i u vremenu u kojem živimo³. Sva dosadašnja iskustva potvrđuju tezu da jednakopravno društvo može postojati samo kao plod ljudske mašte.

U svim poznatim ljudskim društvima postoji neki oblik društvene nejednakosti, s tim da njezini pojavni oblici mogu biti različiti. Očigledno je da se ljudi u društvu međusobno razlikuju. Razlike među ljudima mogu se temeljiti na posve slučajnim ili biološkim obilježjima, dakle,

Wright C. Mills, Elita vlasti, Kultura, Beograd, 1964., str. 461.

2 Utopija grč. ( $u$ - ne + tópos - mjesto, mjesto kojega nema), neostvariva mašta, prvobitno naziv zamišljenoga otoka (The Island of Utopia) gdje je ostvaren socijalistički poredak u djelu T. Morusa, engleskoga mislioca 16. st. Utopijski socijalizam - teorije koje su društvenomu poretku, utemeljenu na privatnome vlasništvu i eksploataciji, suprotstavljale socijalistički ideal (u 16. st. Morus, u 17. st. Campanella, u 19. st. Saint-Simon, Fourier, Owen). Vidi: Bratoljub Klaić, Rječnik stranih riječi, Nakladni zavod MH, Zagreb, 1988., str. 1398.

3 Tako, primjerice, oko 4 \% izraelskoga stanovništva i danas stanuje u zajednicama koje broje od 40 pa sve do 1000 članova, a koje se prvi put osnivaju 1908. godine. Takve su zajednice u svijetu poznate pod nazivom kibuci. Kibuci (hebr. kibutzh) su izgrađeni na ideji jednakopravnosti. Zemlja i imovina u kibucima kolektivne su, a proizvodnja i potrošnja zajedničke. Odrasli i zdravi članovi naporno rade za zajednicu, a od zajednice dobiju sve što im je potrebno (stan, hranu, odjeću). Svaki bračni par dobiva jednu sobu, a njihova djeca jedu, spavaju i najveći dio vremena provode u domovima gdje su podvrgnuti kolektivnomu odgoju. Izvorna je ideologija kibuca cionistička, solidaristička i kolektivistička, ali se u posljednje vrijeme prilagođava tržištu i modernome individualizmu. (Vidi: Aljoša MiMICA - MARIJA Bogdanović, Sociološki rečnik, Zavod za udžbenike, Beograd, 2007., str. 227.) Plaće kao izvori moguće nejednakosti u kibucima ne postoje. Sve važne odluke donosi zajedničko tijelo koje čine svi odrasli članovi kibuca. Izvanjsko promatranje upućuje na zaključak da u njima postoji jednakopravnost kao načelo življenja. Međutim, neki su analitičari u kibucima uočili dva međusobno različita društvena sloja. Jedni su rukovoditelji koji organiziraju i usmjeravaju rad drugih (ta im činjenica osigurava visok ugled i privilegiranu društvenu poziciju), a drugi su obični ljudi. 
mogu postojati kao posljedica osobnih odlika pojedinaca (prirodne razlike kao što su boja očiju ili visina, vještine, talenti, inteligencija) ili mogu proizlaziti iz uvjeta društvenoga života. „Međutim, treba biti jasno da nema čistih prirodnih razlika, jer su sve, pa i prividno čisto biologijske razlike među ljudima (visina, težina, intelektualni potencijal, snaga, brzina, morfološka i fiziologijska struktura itd.) dijelom društveno uvjetovane.“" Zajednički život ljudi dovodi do društvene diferencijacije, pojave koja se odnosi na proces društvene podjele rada, koja pojedincima dodjeljuje funkcije, dakle društvene uloge i položaje. Rezultat su toga univerzalnog procesa društvene razlike koje, općenito shvaćeno, obuhvaćaju sve razlike među ljudima bez obzira na to radi li se o nestrukturiranim ili strukturiranim razlikama. Iz tih razlika proizlazi različita razina moći i društvenoga ugleda pojedinca. Pojam društvenih razlika u načelu odnosi se na razlike između pojedinaca, a ne skupina. Da bi društvo moglo funkcionirati, neophodna je odgovarajuća podjela uloga onima koji će ih najuspješnije izvršavati. Te uloge i položaji razlikuju se po svome značenju za život i funkcioniranje društva. Za njih su potrebne odgovarajuće vještine i sposobnosti, ali i odgovarajuće školovanje. Različitost društvenih položaja i društvenih uloga ne mora ujedno značiti i njihovo rangiranje. Drugim riječima društvena nejednakost može postojati i bez društvenih slojeva.

Poseban je oblik društvene nejednakosti društvena stratifikacija koja se razumije kao „strukturirana, stabilna i trajna nejednakost među grupama ljudi u nekom društvu, a koje su na temelju moći, ugleda i bogatstva njenih članova rangirane jedna iznad druge ${ }^{{ }^{5}}$. Sama riječ izvorno potječe iz geologije i označava slojeve Zemljine kore poredane jedne iznad drugih. Ta je predodžba važna u proučavanju društvene stratifikacije jer je riječ o hijerarhijski poredanim društvenim skupinama slojevima. Nejednaka raspodjela rijetkih društvenih vrijednosti i dobara dovodi do toga da je različite društvene skupine moguće rangirati

4 Gordana Cerjan-Letica i dr: Medicinska sociologija, Medicinska naklada, Zagreb, 2003., str. 115.

5 Michael Haralambos - Robin Herald, Uvod u sociologiju, Globus, Zagreb, 1989., str. 36. 
na više i niže, odnosno dovodi do procesa oblikovanja i reprodukcije strukturiranih stratifikacijskih jedinica - društvenih slojeva. Kada je riječ o dimenzijama društvene stratifikacije, $u$ istraživanjima se najčešće koristi trodimenzionalna koncepcija Maxa Webera. Na nejednakostima položaja društvenih skupina ili slojeva u raspodjeli materijalnih dobara, moći i ugleda formiraju se tri stratifikacijske dimenzije: ekonomska, politička i statusna. Stratifikacijsku skupinu pojedinac ne bira, već se u njoj rađa. Položaj u stratifikacijskome sustavu proizvodi niz posljedica koje se odražavaju na čovjekov život. Pripadnost određenomu društvenom sloju utječe na materijalne uvjete, kakvoću i stil života te na životne šanse.

Različiti teorijski pristupi ${ }^{6}$ društvenoj stratifikaciji različito objašnjavaju društvene nejednakosti između društvenih skupina. Naime, u svakome stratificiranom društvu postoji skup ideja kojima se objašnjava i podupire nejednaka raspodjela društvenoga bogatstva, ugleda i moći. Poznavanje stratifikacijske strukture nužno je za uvid u cjelokupnu strukturu nekoga društva ili zajednice.

Za funkcionaliste društvene su nejednakosti nužne, društveno korisne i instrument su društvene integracije. Ističu važnost motivacije (K. Davis i W. Moore) jer dužnosti i obveze različitih društvenih položaja nisu jednako ugodne, nisu jednako važne za društveni opstanak niti zahtijevaju jednake sposobnosti i darovitosti. Bez motivacije ljudi ne bi obavljali svoje uloge. Stoga moraju postojati nagrade koje se na različit način raspodjeljuju članovima društva. Upravo je ta nejednakost nagrada motivacijski poticaj za ljude. ${ }^{7}$ Ako je stratifikacija funkcionalna, kako drže funkcionalisti, za koga je funkcionalna, pitaju kritičari. Je li funkcionalna za društvo u cjelini ili samo za povlaštene skupine ljudi?

Utemeljitelj marksističke teorije i preteča modernih konfliktnih teorija Karl Marx na pitanje o klasnoj stratifikaciji odgovara najprije na općem planu ljudske povijesti od antike do modernoga doba, zatim to

6 O teorijskim pristupima društvenoj stratifikaciji vidjeti više: Michael Haralambos Martin Holborn, Sociologija. Teme i perspektive, Golden marketing, Zagreb, 2002., str. 22. -126.

7 Usp. Slavo Kukić, Sociologija. Teorija društvene strukture, Sarajevo Publishing, Sarajevo, 2004., str. 164. 
konkretizira i raščlanjuje na primjeru klasnih borbi u Francuskoj u devetnaestome stoljeću. Smatra da stratifikacija proizlazi iz stalne borbe za oskudne resurse među pojedincima i skupinama. Objašnjenje društvene stratifikacije i sukoba izvodi iz ekonomskih odnosa. Općenito, u Marxovoj teoriji ${ }^{8}$ dominira ekonomski determinizam, a društvena stratifikacija shvaća se kao oblik stabilne i trajne društvene nejednakosti društvenih klasa, i kao takva dezintegrirajuća je, izrabljivačka i društveno štetna. Marx je ostao do kraja života čvrsto uvjeren da su proturječnosti i nehumanost kapitalističkoga načina proizvodnje osnova raznovrsnih otuđenosti čovjeka. Demistifikacija stvarnoga života postiže se ukidanjem privatnoga vlasništva nad sredstvima za proizvodnju i svakoga odnosa u kojem su proizvođači otrgnuti od svojih proizvoda. Kritike Marxove teorije ponajprije su usmjerene na njegovo objašnjenje društvene stratifikacije i sukoba koje izvodi isključivo iz ekonomskih odnosa. I drugi činitelji mogu biti osnova stratifikacije i sukoba: religijski, rasni, nacionalni i slično. ${ }^{9}$ Marxovoj su teoriji snažan udarac zadali politički režimi 2o. stoljeća. Nekadašnje su zemlje realsocijalizma (socijalistička društva) pozivanjem na Marxa ukinule privatno vlasništvo nad sredstvima za proizvodnju, ali je veliki stupanj nejednakosti ipak ostao, a počivao je na političkoj moći.

Originalan i prihvatljiv pristup u istraživanju društvene stratifikacije čini se pristup američkoga sociologa Pitirima A. Sorokina ${ }^{10}$ koji ne pravi

8 Karl R. Popper ističe: „Marx se nije borio protiv bogatstva niti je hvalio siromaštvo. Nije mrzio kapitalizam zbog njegove akumulacije bogatstva, nego zbog njegovog oligarhijskog karaktera, on ga je mrzio zato što u ovom sistemu bogatstvo znači političku moć u smislu moći nad drugim ljudima. Radna snaga je pretvorena u robu, to znači da ljudi moraju prodavati sebe na tržištu. Marx je mrzio ovaj sistem zato što je on ličio na ropstvo“. Vidjeti više o Marxovu poimanju društvenih klasa, zakonu porasta bogatstva i bijede u: KARL R. Popper, Otvoreno društvo i njegovi neprijatelji. Tom II, Plima proročanstva: Hegel, Marx $i$ posljedice, Pravni centar Fond otvoreno društvo Bosne i Hercegovine, Sarajevo, 1998., str. 200. -238 .

9 Usp. Catherine Halpern - Jean-Claude Ruano-Borbalan, Identitet(i). Pojedinac, grupa društvo, Clio, Beograd, 20o9., str. 145. - 176.

10 Pitirim Sorokin rođen je u zabitome ruskom selu 21. siječnja 1899. godine. Još dok je bio student teologije, uhićen je zbog revolucionarnih aktivnosti i provodi četiri mjeseca u zatvoru. Nakon toga napokon dolazi na Sveučilište u St. Petersburg gdje istražuje, predaje, a bavi se i revolucionarnom djelatnošću, što ga ponovo dovodi u zatvor. Kada je konačno dobio dozvolu da napusti Rusiju i poslije kraćega zadržavanja u Čehoslovačkoj, stiže u SAD 
razliku između društvene diferencijacije i društvene stratifikacije, nego na njih gleda kao na elemente jedinstvenoga društvenog fenomena. Za njega stratifikacija znači diferencijaciju stanovništva u hijerarhijski postavljene klase; ogleda se u postojanju viših i nižih slojeva.

\begin{abstract}
Njezina osnova i sama bit sastoji se od nejednako raspoređenih prava i privilegija, dužnosti i odgovornosti, društvenih pogodnosti i lišavanja društvene moći i utjecaja među članovima društva. Konkretni oblici društvene stratifikacije su brojni i različiti. Ako je ekonomski položaj članova jednog društva nejednak, ako među njima ima bogatih i siromašnih društvo je ekonomski raslojeno, bez obzira na to je li njegova organizacija komunistička ili kapitalistička, stoji li u njegovu ustavu društvo ravnopravnih pojedinaca ili ne. Etikete, natpisi i reakcije na govore ne mogu promijeniti niti izbrisati realnu činjenicu ekonomske nejednakosti, koja se ogleda u razlikama u prihodima i ekonomskom standardu, u postojanju bogatih i siromašnih slojeva. ${ }^{11}$
\end{abstract}

Sorokin nadalje ističe, ako se društveni slojevi u okviru jedne zajednice mogu rangirati $u$ odnosu na autoritet i prestiž, ako postoje upravljači i oni kojima se upravlja, onda, kako god se oni nazivali (carevi, izvršna vlast, gazde, šefovi), to znači da je ta zajednica politički raslojena, bez obzira na to što piše u njezinu ustavu ili što je proklamirano njezinim deklaracijama. Pored ekonomskoga i političkoga raslojavanja i nejednakosti pripadnici nekoga društva mogu biti podijeljeni u razne grupe prema zanimanjima, a neka se zanimanja smatraju časnijim od drugih. Ako su pripadnici jedne grupe zanimanja podijeljeni na šefove različitih autoriteta i na pripadnike koji su podređeni tim šefovima, ta je zajednica raslojena prema zanimanjima, bez obzira na to jesu li šefovi izabrani ili postavljeni i jesu li dosegli svoj položaj društvenim nasljeđivanjem ili osobnim dostignućem, smatra Sorokin. Iako su konkretni

u listopadu 1923. Isprva drži predavanja na raznim sveučilištima, no uskoro dobiva stalno namještenje na Sveučilištu u Minnesoti. Njegove knjige Socijalna pokretljivost i Suvremene sociološke teorije priskrbile su mu nacionalni ugled i 1929. ponuđeno mu je (što je i prihvatio) prvo predavačko mjesto sociologa na Sveučilištu Harvard. Tada završava rad koji će postati njegovim najpoznatijim djelom: Socijalna i kulturna dinamika. Umro je 11. veljače 1968.

${ }^{11}$ Pitirim Sorokin, Social and Cultural Hability, The Free Press, Glencoe III., 1939., str. 11. $-13$. 
oblici društvene stratifikacije raznovrsni, većina ih se može svesti na tri glavne kategorije: ekonomsku, političku i profesionalnu. Može se uzeti kao opće pravilo da su ti oblici usko povezani jer je uobičajeno da onima koji zauzimaju više pozicije $u$ jednome smislu pripadaju više pozicije i $u$ drugim aspektima, i vice versa. Ljudi koji pripadaju višim ekonomskim slojevima često su i u višim političkim i profesionalnim slojevima. Siromašni, kao po nekome pravilu, lišeni su ekonomske, političke i profesionalne moći, oni pripadaju najnižim slojevima društvene hijerarhije. To je opće pravilo, mada ima izuzetaka.

\subsection{Jesu li društvene klase nestale?}

Već dugo širi se ideja da pojam društvene klase nije pogodan za analiziranje suvremenih razvijenih društava. Sociolog Robert Nisbet 1959. objavio je Pad i nestajanje društvenih klasa i naveo sve razloge zbog kojih, po njegovu mišljenju, društvene klase trebaju nestati. Od toga vremena ta se teorija širila, a njezini su argumenti više ili manje prihvaćani. Ima, dakle, šezdeset godina da se sociolozi trude pokazati kako su društvene klase nestale. Međutim, kada izbliza promatramo prirodu, oblike i stupanj nejednakosti koji postoje u suvremenome društvu, teorija o kraju društvenih klasa posljednjih je tridesetak godina bila suočena s brojnim paradoksima. Tako, primjerice, danas dok se društvene nejednakosti ponovo uspostavljaju i produbljuju, društvene klase postaju predmetom osporavanja do te mjere da postaju tabu-tema.

Društvena klasa je sociološka kategorija koja se, zavisno od teorijske orijentacije, različito definira i koristi. Taj pojam najveću važnost ima u teorijama koje vertikalnu društvenu nejednakost, kao i cjelokupnu društvenu strukturu i promjene, sagledavaju u kategorijama postojanja društvenih klasa i njihovih međusobnih sukoba. Iako je društvena misao vrlo rano otkrila da se sve društvene razlike između ljudi u krajnjoj liniji svode na razlike u materijalnome bogatstvu i pogodnostima za stjecanje dohotka ili, drugim riječima, da je privatna svojina uzrok podjele društva na klase ili slojeve koji zauzimaju različite položaje u društvenoj strukturi, ipak se ekonomsko tumačenje društvene nejednakosti obično 
vezuje za ime Karla Marxa. Po njegovu mišljenju društvene klase javljaju se s porastom proizvodnih snaga, proširenjem društvene podjele rada, nagomilavanjem bogatstva i uspostavljanjem privatne svojine. Smatrao je da klasna podjela društva ima dihotomni oblik, naime, u svakome društvu postoje dvije osnovne klase: vladajuća i podčinjena, s tim da prva eksploatira drugu držeći je u pokornosti. Te dvije klase razlikuju se po mnogim obilježjima: jedna je od njih bogata, a druga siromašna; jedna uživa veliki društveni ugled, druga obavlja djelatnosti koje se u društvu manje cijene; jedna posjeduje veliku društvenu moć i presudno utječe na razne društvene procese i odnose, druga je nemoćna i manje ili više zavisi od one prve. Za sve te društvene razlike od presudne je važnosti svojina nad sredstvima za proizvodnju ${ }^{12}$. Glavna Marxova teza - da društvene klase postoje samo kroz klasnu borbu - na više je mjesta eksplicitno istaknuta, posebno u Osamnaestom brimeru Luja Bonaparte (1852.). U tome spisu uzgred se daje jedna relativno cjelovita definicija društvene klase: to bi bile velike grupe ljudi („milijuni porodica“) koje žive pod sličnim ekonomskim uvjetima, čiji su način života, interesi i obrazovanje različiti od drugih grupa, iz čega proizlaze njihove neprijateljske suprotstavljenosti i sukobi. Na toj osnovi načinjena je razlika između pojmova klasa po sebi i klasa za sebe. ${ }^{13}$ Ukratko, u marksističkoj tradiciji društvena je klasa na objektivan način povezana s nejednakom raspodjelom vlasništva nad sredstvima za proizvodnju, iz čega proizlazi eksploatacija radničke klase od vlasnika sredstava za proizvodnju. I jedni i drugi nalaze se u specifičnim „klasnim situacijama“ koje omogućavaju da se uoče „klase po sebi“. To nije sve, društvena klasa iskazuje se i kroz svijest koju imaju njezini članovi, a to je da dijele istu sudbinu i da se trebaju organizirati u borbi protiv eksploatacije. ${ }^{14}$ Za Karla Marxa nema radničke klase bez radničkoga, političkoga i sindikalnoga pokreta: tada je klasa po sebi i za sebe. Pristalicama nestanka društvenih klasa ta je definicija vrlo pogodna jer s određenim povećanjem dohotka,

12 Vidi: Minailo Đurić, Sociologija Maxa Webera, Matica hrvatska, Zagreb, 1964.

13 A. Mimica, AljošA - M. Bogdanović, $n$. dj., str. 231.

14 Vidi: Ralf Dahrendorf, Class and Class Conflict in Industrial Society, Stanford University Press, Stanford, 1959. 
smanjenjem broja radnika i s opadanjem sindikalnoga pokreta očigledno je da su društvene klase mrtve.

Ako se uzme jedna manje radikalna definicija društvene klase, na primjer ona M. Webera, stvar je drugačija. Nasuprot Marxu, Weber je smatrao da su materijalno bogatstvo, društveni ugled i društvena moć tri osnovne i relativno samostalne dimenzije društvene slojevitosti koje nije moguće svesti na jedan zajednički imenitelj. U Weberovu višedimenzionalnom shvaćanju društvene strukture ne nalazi se interes za praktično-političke implikacije sociološkoga proučavanja društvene stvarnosti niti se nalazi interes za njezino revolucionarno mijenjanje. On želi razumjeti postojeću društvenu stvarnost i uzročno objasniti.

Prema njemu, društvene klase su grupe pojedinaca razvrstanih po različitim klasnim situacijama i „životnim šansama“ ili „mogućnostima razvoja“, koji zavise od njihovih resursa, odnosno od kvalifikacije. Ako te "sudbine“ odgovaraju velikim frakcijama stanovništva, onda se može govoriti o društvenim klasama. Weber je naglašavao da su klase obični društveni agregati, a ne organizirane grupe. Smatra da društvene razlike među ljudima nisu samo klasne razlike, da se u klasnoj podjeli društva iskazuje samo jedna dimenzija društvene slojevitosti. Druge dvije dimenzije društvene slojevitosti su društveni ugled i društvena moć. Po Weberu raspodjela društvenoga ugleda ne podudara se s raspodjelom materijalnoga bogatstva jer često se događa da oni koji posjeduju veliku ekonomsku moć ne uživaju nikakav društveni ugled, i obrnuto. No, tijekom vremena po pravilu dolazi do uspostavljanja ravnoteže između ovih dviju dimenzija društvene slojevitosti.

Za razliku od pojma društvena klasa, koji se najčešće vezuje za diferencijaciju ljudi na temelju njihova ekonomskog bogatstva, Weber upotrebljava izraz društveni sloj da bi njime označio „karakteristično postojeće pravo u odnosu na pozitivnu ili negativnu privilegiju u pogledu društvenog ugleda“, a da bi što jasnije istakao

relativnu samostalnost društvenog ugleda prema klasnom položaju, Weber uvodi i pojam staleža. Sve društvene razlike koje se tiču ocjene časti i prestiža on naziva staleškim razlikama. Što je još važnije, smatra da se te razlike po pravilu kristaliziraju u relativno trajnim društvenim oblicima 
te da staleške razlike snažno utječu na stvaranje društvenih slojeva kao realnih društvenih oblika. ${ }^{15}$

Weber smatra da društvenu moć, kao treću dimenziju društvene slojevitosti, treba razumjeti kao sposobnost da se utječe na ponašanje drugih i da političke stranke predstavljaju organizirane grupe preko kojih pripadnici pojedinih klasa ili slojeva brane svoje interese i nastoje nametnuti svoju volju državi. Prvi je zapazio da je odnos između raspodjele materijalnoga bogatstva, društvenoga ugleda i društvene moći vrlo kolebljiv na ljestvicama društvene hijerarhije, osobito u razdobljima naglih društvenih promjena izazvanih ratnim zbivanjima ili tehničko-ekonomskim dostignućima. Veza između ovih triju komponenata društvene slojevitosti vrlo je čvrsta u razdobljima relativna mira i društvene ravnoteže.

Suvremeni francuski teoretičar Louis Chauvel ističe da, kada je riječ o društveno-ekonomskim grupama koje nejednako raspolažu obrazovnim, nasljednim i drugim resursima, legitimno je govoriti o društvenim klasama ako su potvrđena tri kriterija klasnoga identiteta. Prije svega vremenski identitet koji podrazumijeva trajnost grupe, njezinu društvenu reprodukciju, a posebno njezinu zatvorenost prema društvenim kretanjima; potom kulturni identitet, činjenica da su im zajednički način života i rada, jezik i kulturne crte koje im omogućuju međusobno prepoznavanje i, na kraju, grupni identitet, odnosno sposobnost da se djeluje složno, prema istomu cilju, politički potaknuti sviješću o zajedničkim kolektivnim interesima. Ovaj je identitet bitno potisnut. Iako analize ovih kriterija klasnoga identiteta pokazuju da su klasne granice od pedesetih do osamdesetih godina dvadesetoga stoljeća nestale, besklasno društvo još je vrlo daleko od nas. ${ }^{16}$ Nakon brojnih analiza može se zaključiti da je svaka organizirana društvena zajednica slojevito društveno tijelo. Neslojevito društvo u povijesti čovječanstva nikada nije ostvareno. Ako ne možemo naći neslojevito društvo u najprimitivnijim zajednicama, beskorisno ga je tražiti u većim, složenim društvima.

$15 \quad$ M. ĐURIĆ, $n$. dj., str. 145.

16 Vidi: isto. 
Stratifikacijski oblici i proporcije variraju, ali njezina bit postoji svugdje i u svim vremenima.

\section{Siromaštvo - kuda ide ovaj svijet}

Siromaštvo je povijesna konstanta. Nalazimo ga u svim ljudskim zajednicama kroz povijest pa sve do danas. U prvim ljudskim zajednicama bilo je povezano s pukim fizičkim preživljavanjem. Tijekom povijesti siromaštvo se sadržajno i konceptualno mijenjalo, mijenjalo je svoj opseg i intenzitet, a mijenjao se i odnos društva prema siromašnima.

Porast materijalnoga bogatstva u društvu vodio je stvaranju uočljivih društvenih nejednakosti, dakle, došlo je do izdvajanja manjine koja nije bila opterećena svakodnevnim preživljavanjem i većine koja je svakodnevno vodila borbu za održavanje "gole egzistencije“. S pojavom prvih klasnih društava koja su poznata po ekstremnim nejednakostima siromaštvo se počinje promatrati patološkom pojavom. Reakcije građana i javne vlasti na siromaštvo bile su ambivalentne $\mathrm{e}^{17}$, postojala je spremnost da se pomogne siromašnim skitnicama, ali je postojao i prezir prema njima kao pojedincima koji nisu u potpunosti ljudska bića. U srednjem vijeku veliki je broj ljudi bio osuđen na lutanje, prosjačenje i milostinju ${ }^{18}$. To je vrijeme u kojem dominira ekonomija spasa. Crkvena vlast upravlja društvom i spasom ljudi, prikuplja i dijeli dobra. U 11. i 12. stoljeću

${ }_{17}$ Vidi više: Zoran Šućur, Siromaštvo. Teorije, koncepti i pokazatelji, Pravni fakultet, Zagreb, 2001.

18 U srednjem vijeku crkva je definirala odnos prema siromašnima, razvila je etiku milosrđa. Milosrde i pomaganje siromašnima smatrani su kršćanskom obvezom i sredstvom otkupljenja grijeha. Odnos Crkve prema siromašnima nije bio istovjetan jer se razlikovalo siromaštvo iz nužde i siromaštvo po izboru, također se pravila razlika između dostojnih siromašnih (djeca, starci i bolesni) i nedostojnih siromašnih (tu se ubrajaju svi oni koji mogu raditi, ali to ne čine, već se odaju skitnji i prosjačenju). U patrističkim spisima siromaštvo (pauperitas) je vezano uz poniznost (humilitas). Posebno se slavi kao svjestan izbor, gdje nije u igri antinomija bogatstvo - siromaštvo, nego moćnik - siromah (potens-pauper). Dakle, siromaštvo nije vrlina po sebi, nego je vrlina opredjeljenje za njega, odbacivanje materijalnoga bogatstva i moći kako bi se služilo Bogu. O siromaštvu i milosrđu u srednjem vijeku vidjeti u: Vlado Puljız i dr.: Socijalna politika. Povijest, sustavi i pojmovnik, Pravni fakultet, Zagreb, 2005., str. $41 .-49$. 
utemeljene su institucije poput bolnica, azila i sirotišta kojima je cilj bio pomaganje siromašnima, bolesnima, starima i djeci ${ }^{19}$.

Moderno je društvo prije svega industrijsko društvo, a industrijalizacija je uzrok najsnažnijih promjena. Te su promjene najsnažniji učinak imale u Europi u kojoj se stvara nova kultura, nov način života i nove vrijednosti. ${ }^{20} \mathrm{U}$ modernoj epohi čovjek je postao gospodar samoga sebe i svijeta u kojem živi. Ukratko,

Bilanca tisućljeća čini se prilično jednostavnom. Od svijeta velikih i malih carstava i kraljevina, više-manje jednakih po bogatstvu i moći, postali smo svijet nacionalnih država, s tim da su neke daleko bogatije i jače nego druge. Od nekoliko stotina milijuna ljudi postali smo više od sedam milijardi i računamo na još. Od rada sa skromnim pomagalima i tehnikama, postali smo gospodari velikih strojeva i nevidljivih snaga. Prešli smo put od inteligentnog promatranja i snalaženja do golemog i rastućeg znanstvenog znanja koje generira trajan tok korisnih primjera. ${ }^{21}$

Napredak znanosti, tehnologije, intelektualne i materijalne moći većinom je služio dobru, iako su svi ovi elementi često bili zloupotrebljavani za destruktivne ciljeve ili su naprosto bili upotrebljavani s nenamjernim, ali katastrofalnim posljedicama.

U novome vijeku nadzor i skrb nad siromašnima počinje preuzimati svjetovna vlast. Društvene zajednice i država sve više preuzimaju onu ulogu koju je ranije imala Crkva. Ovo je vrijeme izražene represije prema siromašnima ${ }^{22}$, ali i doba kada se oblikuje ideja da siromašni imaju pravo zarađivati za život, da njihova djeca imaju pravo rasti u svome

19 U većim gradovima postojala su i mjesta na kojima su se okupljale skitnice. Ta mjesta krajnje bijede u francuskoj literaturi podrugljivo su nazvana Les cours des miracles (dvorovi čuda).

20 Usp. Irena Musa, Kulturni identitet u vrtlogu globalizacije. Bosna i Hercegovina neravni svijet, Filozofski fakultet Sveučilišta u Mostaru, Mostar, 2013., str. 117. - 126.

${ }^{21}$ David S. LANdes, Bogatstvo i siromaštvo naroda. Zašto su neki tako bogati a neki tako siromašni, Masmedia, Zagreb, 2003., str. 645.

${ }_{22}$ Michel Foucault u svome djelu Ludilo i civilizacija (Madness and Civilization, 1976.) ističe da su vlasti do 18. stoljeća vrlo rijetko pokušavale kontrolirati, regulirati ili čak nadgledati ponašanje masa populacije. Fenomeni poput nezaposlenosti, siromaštva i ludila počeli su se smatrati društvenim problemima u državama 18. stoljeća. Foucault tvrdi da je ta promjena nastupila zbog novoprobudene zabrinutosti u europskoj kulturi u pogledu odgovornosti za socijalne probleme i zbog razvoja nove radne etike. Društvo je osjećalo da je potrebno učiniti nešto s ludima, a ostali su kažnjavani zbog novoga grijeha - lijenosti. 
domu i zavičaju i izučiti svoj posao ili zanat. Krajem 19. i početkom 20. stoljeća veliki broj europskih zemalja ustanovljuje državno socijalno osiguranje kao branu siromaštvu i drugim velikim rizicima. U drugoj polovici 20. stoljeća ekstremno siromaštvo sve se više analizira u kontekstu ljudskih prava. Neposredno nakon Drugoga svjetskog rata siromaštvo je prestalo biti predmet interesa političara pa i znanstvenika na Zapadu, što se može objasniti socijalno-ekonomskim trendovima toga vremena. To su godine ekonomskoga prosperiteta u većini zapadnih zemalja. Stope nezaposlenosti bile su vrlo niske, a ekonomski rast doveo je do poboljšanja standarda većine stanovništva. To je razdoblje nastajanja tzv. društva obilja, u kome su realni indikatori potakli optimističke prognoze u pogledu ublažavanja, pa čak i potpunoga dokidanja siromaštva. Međutim, u 1960-im godinama dolazi do ponovnoga otkrića siromaštva u modernim društvima, ne zbog općega trenda osiromašivanja društva, nego zbog povećanja svijesti o socijalnim nejednakostima i dohodovnim razlikama. U 1970-im godinama većina razvijenih zemalja prolazi kroz određenu ekonomsku recesiju, što je dovelo do povećanja nezaposlenosti te stagniranja ili opadanja ekonomskoga rasta. Sada se donekle mijenja odnos prema siromašnima i nezaposlenima. Na njihove poteškoće ne gleda se više sa simpatijama, nego ih se čak nastoji okriviti kako za vlastitu situaciju tako i za nastale nacionalne i ekonomske probleme ${ }^{23}$. U 1980-im godinama siromaštvo počinje pogađati znatno veće dijelove populacije razvijenih zemalja. Broj siromašnih brzo se povećavao, počeo je obuhvaćati nove kategorije ljudi koje do tada nisu bile siromašne.

Nekada se govorilo da je siromaštvo posebno i nepromjenjivo stanje jednom siromah, uvijek siromah. „Nova saznanja govore da ... siromaštvo ima više lica. ${ }^{\prime 24}$ Mnogo je različitih vrsta siromašnih oblasti i sredina

${ }_{23}$ Siromašni su okrivljivani za svoje stanje i u prvim, individualističkim teorijama siromaštva, koje su bile raširene u devetnaestome stoljeću. Osobito oštar kritičar siromaha toga vremena bio je Herbert Spencer (1820. - 1903.) koji je skovao izraz „opstanak najsposobnijih“. Smatrao je da društvo mora omogućiti najsposobnijima i najmarljivijima da dobiju nagrade za svoj trud. Nesposobni, lijeni, niškoristi, protuhe, slabi trebaju biti osuđeni na život u siromaštvu jer jedino to i zaslužuju. Siromaštvo je društvu potrebno, ono je marljivim članovima društva poticaj za rad.

24 Lutz Leisering - Stephan Leibfried, Time and Poverty in Western Welfare States, Cambridge University Press, Cambridge, 2001., str. 239. Autori su u Njemačkoj izvršili opsežna 
čije siromaštvo potječe od različitih uzroka. Stoga strategije borbe protiv siromaštva mogu biti veoma različite. Siromaštvo nije statičkoga karaktera. U prošlosti je bilo vrlo malo analiza siromaštva, ako ih je uopće bilo. Današnje analize te vrste mijenjaju naše shvaćanje toga fenomena. Anthony Giddens apostrofira da je

Isticanje značaja doba i životnog vijeka, posebno značajno kada je riječ o postindustrijskim društvima jer su u njima kretanja i njihova spajanja izraženiji nego u ranijim periodima. Daleko veći broj ljudi prolazi kroz periode siromaštva nego što se nekad mislilo, ali većina tih perioda kratko traje. Za siromaštvo se prije može reći da predstavlja jednokratno nego trajno iskustvo. No, pojedinci i domaćinstva često prolaze kroz niz perioda siromaštva - takozvani karusel efekt. ${ }^{25}$

Giddens ističe da razdoblja siromaštva kroz koje pojedinci i domaćinstva u zemljama zapadne Europe prolaze najčešće traju jednu do dvije godine, a rijetko se događa da traju pet godina i više. Mnogi ljudi koji žive u siromaštvu uspijevaju iz njega izaći, iako njihova mobilnost može biti kratka vijeka. Izgleda da su ulazak i izlazak iz siromaštva fluidniji nego što se ranije vjerovalo. Međutim, dugotrajno siromaštvo ili siromaštvo kao stalan način života danas predstavlja veliki problem $\mathrm{u}$ mnogim zemljama svijeta.

Još od posljednjega desetljeća dvadesetoga stoljeća u istraživanjima društvenih nejednakosti i siromaštva sveprisutan je pojam jaz. Tim se pojmom naglašava koliko su bogatstvo i dobitci što ih donose znanje i nove tehnologije neravnomjerno raspodijeljeni u svijetu. $S$ jedne strane stvoren je spektakularno bogat svijet, a s druge strane stvoren je zabrinjavajuće osiromašen svijet u kome dominira strašno siromaštvo i užasna neimaština. Danas je taj svijet nejednakosti i raznolikosti, grubo gledano, podijeljen

istraživanja siromaštva po dobima. Ističu osnovne karakteristike siromaštva u postindustrijskim društvima. To su: temporalizacija (iskustvo siromaštva zavisi od njegova trajanja), demokratizacija (siromaštvo pogađa veliki broj ljudi i ne znači obvezno društveno isključenje) i siromaštvo je u velikoj mjeri biografske naravi (povezano je s konkretnim događajima u životu kao što su gubitak posla, bolest, razvod braka, napuštanje roditeljskoga doma). Vidi: isto, str. 240. - 242.

25 Anthony Giddens, Evropa u globalnom dobu, Clio, Beograd, 2009., str. 98. 
na tri vrste narodâ: one koji troše mnogo novca da im ne poraste težina; one čiji ljudi jedu da bi preživjeli; i one čiji ljudi ne znaju od kuda će im doći slijedeći obrok. Zajedno s ovim razlikama dolaze oštri kontrasti u pogledu stopa bolesti i očekivanog životnog vijeka. Ljudi bogatih naroda brinu o svojoj starosti, koja postaje sve duža. Vježbaju da bi ostali u dobroj formi, mjere i suzbijaju kolesterol. ... U međuvremenu ljudi siromašnih zemalja pokušavaju ostati živi. Ne trebaju brinuti o kolesterolu i masnim arterijama, dijelom zbog posne hrane, dijelom jer umiru rano. ${ }^{26}$

Ahilova peta globalnoga doba jaz je između bogatih i siromašnih društava. Svjedoci smo da se u nekim zemljama stanje ne poboljšava, već one postaju još siromašnije, relativno, a ponekad i apsolutno. Landes ističe da su zadatak i interes bogatih zemalja

pomoći siromašnima da postanu zdraviji i bogatiji. Ako to ne učinimo, siromašne zemlje nastojat će uzeti što ne mogu napraviti; a ako ne mogu zaraditi izvozom robâ, izvozit će ljude. Ukratko, bogatstvo je neodoljiv magnet; a siromaštvo je potencijalno žestoko sredstvo zagađivanja; nije ga moguće segregirati te naš mir i prosperitet ovise na dugi rok o blagostanju drugih. ${ }^{27}$

Sama riječ siromaštvo implicira nepoželjno društveno stanje, društveni problem; upućuje na to da pojedincima i skupinama koji su siromašni treba pomoći kako bi se njihovo stanje promijenilo. Siromaštvo je neravnomjerno raspodijeljeno u svijetu, ono u većem ili manjem opsegu prožima sve dijelove svijeta. Očituje se na različite načine među kojima su: nedostatak dohotka i sredstava potrebnih da se osigura održiva egzistencija, glad i neuhranjenost, slabo zdravlje, nedostupnost ili ograničena dostupnost u obrazovanju, povećana smrtnost, uključujući smrtnost od bolesti i gladi, beskućništvo i neodgovarajući stambeni uvjeti, nesigurno okruženje, društvena diskriminacija i izolacija itd. Siromašni su ljudi na društvenoj margini. Mnogi siromašni opisuju svoje stanje kao nemogućnost preuzimanja kontrole nad vlastitim životom. Siromaštvo gura ljude u ropski položaj.

26 D. LANDES, $n$. dj., str. 20.

27 Isto, str. 21. 
U suvremenom društvu siromaštvo $i$ glad u smrt su gurnuli milijune ljudskih bića. „To je apsurd i ljaga koju nijedan razlog ne može opravdati, nijedna politika ozakoniti. Radi se o zločinu protiv čovječanstva koji se beskonačno ponavlja. ${ }^{28} \mathrm{FAO}^{29}$ razlikuje konjunkturnu i strukturalnu glad. Konjunkturna glad posljedica je žestokog pada gospodarstva neke zemlje, a strukturalna je izazvana nerazvijenošću zemlje. ${ }^{30}$

U kojem god obliku da se pojavljuju, siromaštvo i glad izazivaju slabljenje motivacije, isključenje iz aktivna života, društvenu marginalizaciju, osjećaj tjeskobe i poniženosti, osjećaj srama i gubitka ljudskoga dostojanstva.

Neki autori fenomen društvene isključenosti identificiraju s fenomenom siromaštava. Ako se društvena isključenost analizira isključivo na materijalnome planu, tada se pojmovi isključenosti i siromaštva najčešće poklapaju. René Lenoir (Isključeni, 1974.) odbacuje ideju po kojoj se društvena isključenost svodi na ekonomsko siromaštvo. Smatra da društveno isključivanje obuhvaća sve osobe koje su na bilo kojoj osnovi odbačene ili osjećaju da ih društvo odbacuje. Tako je novi pojam društvene isključenosti proširen na svaku situaciju u kojoj dolazi do prekida odnosa između pojedinca i društva. Dakle, novi koncept društvene isključenosti izvorno je „francuski“ koncept kojim su se analitički opisivali novo siromaštvo, nezaposlenost i prostorna segregacija. Taj koncept postao je tijekom posljednjih godina važan analitički konstrukt u Europskoj uniji i u ostatku Europe. Osnova analize jest dualizam isključenosti i uključenosti (izvan i unutra), a razlikuje se od vertikalnoga modela po tome što društvene nejednakosti ne promatra kao stupnjevane nejednakosti između različitih klasa, slojeva, starosnih grupa itd., nego se u fokusu analize nalazi društveni rascjep koji dijeli društvo na one koji mu pripadaju i one isključene. ${ }^{31}$ Pojam društvene isključenosti još je uvijek maglovit i opterećen različitim značenjima, što rezultira poteškoćama u

28 JeAn Ziegler, Imperij srama. Refeudalizacija svijeta, Izvori, Zagreb, 2007., str. 97.

29 Organizacija Ujedinjenih naroda za hranu i poljoprivredu

3o Irena Musa, „Trgovina ljudima - ropstvo 21. stoljeća“, HUM časopis Filozofskog fakulteta Sveučilišta u Mostaru, Mostar, god. XII (2017.) br. 17. - 18., str. 99. - 100.

${ }^{31}$ Usp. Milanka Miković - Sanela Bašić, Odabrane teme suvremene socijalne politike $i$ socijalnog rada, Fakultet političkih nauka, Sarajevo, 2017., str. 35. 
definiranju ${ }^{32}$ i nepostojanju jedne općeprihvaćene definicije. Bez obzira na različite pristupe i izvore društvene isključenosti, ona se najčešće poima kao začarani krug koji ima tri sastavnice: isključenost iz tržišta rada zbog nezaposlenosti, siromaštvo i socijalnu izolaciju. ${ }^{33}$ Društvena isključenost nije uvijek uzrokovana društvenim nesukladnostima, može postojati i kao rezultat osobnoga izbora. To se događa kada osoba svjesno odbacuje norme i vrijednosti društva u kojem živi. Takve osobe najčešće se susreću u zatvorenim društvenim grupama kao što su delikventi, kriminalci, sekte, terorističke grupe itd.

\section{Društvene nejednakosti i siromaštvo u Bosni i Hercegovini}

Kada teoretičari govore o Bosni i Hercegovini, ocjenjuju je „slabom i propalom državom“, govore o njoj kao o „najdublje podijeljenoj europskoj državi“" s različitim interesnim i vrijednosnim sustavima. „Sadašnja postdaytonska Bosna i Hercegovina je nestabilna država, opterećena političkim, ekonomskim, gospodarskim, socijalnim, pravnim, obrazovnim, kulturnim, vjerskim, jezičnim i drugim problemima. Oni su jednim dijelom naslijeđe iz dalje ili bliže prošlosti, a drugim dijelom potencirani razvojem događaja u sadašnjem poratnom vremenu“ ${ }^{{ }^{34} \text {. To je }}$

${ }^{32}$ Primjerice, službenu definiciju pojma socijalne isključenosti dale su političke institucije Velike Britanije: „Društvena isključenost je ukratko pojam koji označava što se može dogoditi kada pojedinci ili cijela područja pate od kombinacije povezanih problema poput nezaposlenosti, neadekvatne obučenosti, niskog prihoda, loših uvjeta stanovanja, okoline s visokom stopom kriminaliteta, lošeg zdravlja i raspada obitelji.“" (U toj definiciji ne spominju se zajednički nazivnici koji uzrokuju socijalnu isključenost.); ili Eurostat Task Force on Social Exclusion iz 1998. godine koji socijalnu isključenost određuje kao „dinamički proces, najbolje opisan kao kretanje prema nižim razinama: određene nepovoljne okolnosti vode prema isključenosti, završavajući s višestruko deprivirajućim okolnostima. Pojedinci, kućanstva i geografska područja mogu biti isključeni iz pristupa vrijednim resursima kao što su zaposlenje, zdravlje, obrazovanje, socijalni i politički život". (Ta definicija pozornost usmjerava na nepovoljne životne okolnosti koje se međusobno isprepliću i podupiru). Vidjeti više: ZORAN ŠUĆUR, „Socijalna isključenost: pojam, pristupi i operacionalizacija“, Revija za socijalnu politiku, Zagreb, god. xxxv. (2004.) br. 1. - 2., str. 45. - 6o.

33 Usp. Predrag Bejaković, Vodič za socijalnu uključenost, Institut za javne financije, Zagreb, 2009., str.6.

34 Vidi: Božo ŽepIĆ, Enigma Bosna i Hercegovina, Logotip, Široki Brijeg, 2002. 
napisao profesor Božo Žepić 2002. godine u svojoj knjizi Enigma Bosna $i$ Hercegovina. Niz događaja vezanih za ratno i poratno vrijeme u Bosni i Hercegovini negativno se odrazio na tranzicijske procese u ovoj državi i opteretio je lošim ugledom u svijetu. Pitamo se što se to promijenilo od toga vremena do danas. Postali smo mnogo siromašniji, a narod svoje siromaštvo i bijedu podnosi u tišini. U tišini ispraća svoju djecu koja odlaze za boljim životom u zapadnu Europu naseljavajući je uzduž i poprijeko. Te slike postale su svakodnevnica bosanskohercegovačke zbilje, s njima se gase nada i optimizam koji su iznimno važni za život svakoga društva.

$\mathrm{Na}$ društvenoj razini u $\mathrm{BiH}$ primjetan je stalni trend porasta stope siromaštva, socijalne isključenosti i društvenih nejednakosti općenito. Iako bosanskohercegovačko društvo nikada nije spadalo u red bogatih društava, današnje siromaštvo gotovo da je bez presedana u njegovoj novijoj povijesti. O tome svjedoči i posljednje istraživanje Eurostata koje je potvrdilo da građani BiH žive najlošijim standardom u Europi.

Prema podatcima dokumenta Napredak $u$ realizaciji Milenijumskih razvojnih ciljeva u BiH iz 2012. godine, 15 \% stanovništva živi ispod apsolutne linije siromaštva što znači da žive s manje od $235 \mathrm{KM}$ mjesečno. U relativnome siromaštvu živi 17,9 \% građana $\mathrm{BiH}$, odnosno s manje od $416 \mathrm{KM}$ mjesečno. To znači da je svako šesto domaćinstvo u $\mathrm{BiH}$ siromašno. Početkom 2016. godine Svjetska banka je BiH svrstala na petu poziciju najsiromašnijih država Europe. Već u sljedećoj godini $\mathrm{BiH}$ nazadovala je za pet mjesta i danas po tko zna koji put zauzima prvo mjesto kada je riječ o siromaštvu njezinih građana u usporedbi sa standardom stanovnika europskih država. Prema nekim procjenama danas se u BiH oko 70 \% građana nalazi u zoni siromaštva, a od njih oko $30 \%$ nema ni za „golu egzistenciju“, preživljavaju zahvaljujući obroku iz javne kuhinje. U BiH su, pored nezaposlenih, u izuzetno teškoj poziciji i dobar dio radnika i umirovljenici. Posljedice siromaštva najviše pogađaju starije osobe, jednoroditeljske obitelji i djecu.

U Bosni i Hercegovini društvene nejednakosti, siromaštvo i socijalna isključenost najvećim su dijelom povezani s posljedicama rata i procesom tranzicije, ali i izlaganjem stanovništva novim vrstama različitih 
rizika kao što su recesija, povećanje nezaposlenosti i proračunski problemi. Međutim, ne smijemo zaboraviti da je u otvorenim društvima obrazovanje usko povezano s vertikalnom društvenom pokretljivošću. Najpprikladniji je društveni mehanizam za bijeg iz nižih društvenih slojeva. Obrazovanje je strateški cilj svakoga „dobrog društva“ jer na ovome svijetu ne postoji pismeno stanovništvo koje je siromašno i nepismeno koje to nije. Osobito je važno za nerazvijene zemlje i zemlje u razvoju, jer bez znanja, stručnosti, poduzetničkoga duha, mobilizacije energije jednoga naroda nema ni razvoja. Prema rezultatima UNESCO-va istraživanja ${ }^{35}$ nepismenost u Bosni i Hercegovini vrlo je visoka. Na temelju toga Bosna i Hercegovina može se svrstati u rang nerazvijenih afričkih zemalja. Ako znamo da je obrazovanje najvažnije raspoloživo sredstvo za poticanje razvitka društva i da je postignuto obrazovanje „najvažniji kanal socijalne promocije pojedinca u suvremenom društvu“ ${ }^{36}$, onda $\mathrm{BiH}$ mora razviti sustav koji će ne samo otvoriti mogućnost obrazovanja mladih slabijega socioekonomskog statusa nego i omogućiti mladim i obrazovanim ljudima ostanak u zemlji.

\section{Zaključak}

Teoretičari su uložili velik trud da bi dokazali da su društvene klase nestale, ali to ne može promijeniti ni izbrisati stvarnu činjenicu ekonomske nejednakosti koja se ogleda u razlikama u prihodima i ekonomskome standardu, u postojanju bogatih i siromašnih slojeva u društvu. Današnje društvo daleko je od jednakopravnosti u raspodjeli rijetkih društvenih resursa jer svjedočimo dramatičnim nejednakostima koje se događaju u svijetu: $u$ trenutku se povećava bogatstvo bogatih, ali u trenutku se povećava i siromaštvo siromašnih. Stvarnost svijeta u kojem živimo stvarnost je u kojoj se ruše sve vrste društava i socijalizacija koje smo poznavali u prošlosti. To je stvarnost $u$ kojoj se ruši san o jednome konačno ujedinjenom svijetu, u kojoj pred bogatstvom kleči mnoštvo

35 Usp. „UNESCO-vo istraživanje: Nepismenost u BiH kao u Africi“, Vijesti.ba, <http://www. vijesti.ba/licnosti-dana-los/69583-Nepismenost-BiH-kao-Africi.html>, (25. I. 2012.).

36 Vlasta Ilišin - Ivona Mendeš - Dunja PotočniK, „Politike prema mladima u obrazovanju i zapošljavanju", Politička misao, Zagreb, god. XL. (2003.) br. 3., str. 58. - 90. 
naroda u agoniji. Danas kada se planet gotovo ruši pod teretom bogatstva, bijeda je stravičnija nego u bilo kojem drugom razdoblju ljudske povijesti. Zbog siromaštva, bijede, pothranjenosti i gladi milijuni ljudskih bića gurnuti su u smrt. Znamo da ne postoji jedinstveni, optimalni model rješavanja siromaštva koji bi vrijedio za sva društva. Povijest nam kaže da su najuspješniji modeli u borbi protiv siromaštva došli iznutra. Inozemna pomoć može koristiti, ali može i štetiti, osobito ako se njome destimuliraju napori i stvara osjećaj nesposobnosti. U tome kontekstu sjetimo se afričke poslovice koja kaže: „Ruka koja prima uvijek je ispod one koja daje." U svakome društvu za uspjeh važni su rad, štedljivost, poštenje, razumijevanje, strpljenje i upornost, jer u konačnici najučinkovitije je oslanjanje na sebe.

Danas u Bosni i Hercegovini oko 70 \% građana živi u zoni siromaštva, od čega oko 30 \% njih nema ni za "golu egzistenciju“. Opsežna ekonomska i socijalna literatura, ali i svakodnevni život, jasno ukazuju na to da sama državna vlast u BiH nije kadra riješiti probleme siromaštva i društvenih nejednakosti. Međutim, kao i svaka druga zemlja, i BiH treba naći i razviti zakonodavni okvir koji bi najbolje odgovarao njezinu povijesnom, socijalnom, kulturološkom i ekonomskom stanju i mogućnostima. Država mora postaviti stabilan zakonski okvir, organizirati socijal$\mathrm{nu}$ infrastrukturu te u suradnji s građanima ustanoviti vladavinu prava. Zbog nepostojanja jasnih zakona i nesklonosti društva da ih poštuje, siromašni i socijalno isključeni najviše trpe. Za ostvarivanje vladavine prava presudne su politička volja i odlučnost vodstva. U ovome svijetu uspijevaju optimisti, ne zbog toga što su uvijek u pravu, nego zbog toga što su pozitivni. Pozitivni su čak i kada griješe, a to je put postignuća, ispravljanja, poboljšavanja i uspjeha. Stoga, ako se u $\mathrm{BiH}$ svi predano posvete radu na smanjenju siromaštva i socijalnome uključivanju, ona može ući u novo doba u kojem će težiti ostvarenju dostojanstvena života za sve stanovnike i stvarati društvo u kojem će se živjeti u prosperitetu, miru, slobodi i sigurnosti. 


\section{Literatura}

- Albrou, Martin, The Global Age, Polity, Cambridge, 1996.

- Bard, Alexander - SØderqvist, JAn, Netokracija - nova elita moći $i$ život poslije kapitalizma, Differo, Zagreb, 2003.

- Bejaković, Predrag, Vodič za socijalnu uključenost, Institut za javne financije, Zagreb, 2009.

- Cerjan-Letica, Gordana i dr., Medicinska sociologija, Medicinska naklada, Zagreb, 2003.

- Dahrendorf, Ralf, Class and Class Conflict in Industrial Society, Stanford University Press, Stanford, 1959.

- Đurić, Minailo, Sociologija Maxa Webera, Matica hrvatska, Zagreb, 1964.

- Foucault, Michel, Madness and Civilization, Tavistok, London, 1967.

- Giddens, Anthony, Evropa u globalnom dobu, Clio, Beograd, 2009.

- Halpern, Catherine - Ruano-Borbalan, Jean-Claude, Identitet(i). Pojedinac, grupa društvo, Clio, Beograd, 2009.

- Haralambos, Michael - Herald, Robin, Uvod u sociologiju, Globus, Zagreb, 1989.

- Haralambos, Michael - Holborn, Martin, Sociologija. Teme i perspektive, Golden marketing, Zagreb, 2002.

- Ilišin, Vlasta - Mendeš, Ivona - Potočnik, Dunja, „Politike prema mladima u obrazovanju i zapošljavanju“, Politička misao, Zagreb, god. XL. (2003.) br. 3., str. 58. - 90.

- Klaić, Bratoljub, Rječnik stranih riječi, Nakladni zavod MH, Zagreb, 1988.

- Kukić, Stavo, Sociologija. Teorija društvene strukture, Sarajevo Publishing, Sarajevo, 2004.

- LAndes, David, Bogatstvo i siromaštvo naroda. Zašto su neki tako bogati a neki tako siromašni, Masmedia, Zagreb, 2003. 
- Leisering, Lutz - Leibfried, Stephan, Time and Poverty in Western Welfare States, Cambridge University Press, Cambridge, 2001.

- Mimica, Aljoša - Bogdanović, Marija, Sociološki rečnik, Zavod za udžbenike, Beograd, 2007.

- Musa, Irena, Kulturni identitet u vrtlogu globalizacije. Bosna $i$ Hercegovina neravni svijet, Filozofski fakultet Sveučilišta u Mostaru, Mostar, 2013.

- Musa, Irena, „Trgovina ljudima - ropstvo 21. stoljeća“, HUM: časopis Filozofskog fakulteta Sveučilišta u Mostaru, Mostar, god. XII. (2017.) br. 17. - 18., str. 88. - 112.

- Miković, Milanka - Bašić, Sanela, Odabrane teme suvremene socijalne politike $i$ socijalnog rada, Fakultet političkih nauka, Sarajevo, 2017.

- Mills, C. Wright, Elita vlasti, Kultura, Beograd, 1964.

- Popper, R. Karl, Otvoreno društvo i njegovi neprijatelji. Tom II, Plima proročanstva: Hegel, Marx i posljedice, Pravni centar Fond otvoreno društvo Bosne i Hercegovine, Sarajevo, 1998.

- Puljiz, Vlado i dr.: Socijalna politika. Povijest, sustavi i pojmovnik, Pravni fakultet, Zagreb, 2005.

- Sorokin, A. Pitirim, Social and Cultural Hability, Glencoe III., The Free Press, 1939.

- ŠUćUr, Zoran, Siromaštvo. Teorije, koncepti i pokazatelji, Pravni fakultet, Zagreb, 2001.

- ŠUĆUR, Zoran, „Socijalna isključenost: pojam, pristupi i operacionalizacija“, Revija za socijalnu politiku, Zagreb, god. xxxv. (2004.) br. 1. - 2., str. 45. - 60.

- „UNESCO-vo istraživanje: Nepismenost u BiH kao u Africi“, Vijesti.ba, <http://www.vijesti.ba/licnosti-dana-los/69583-Nepismenost-BiH-kao-Africi.html>, (25. I. 2012.).

- Ziegler, Jean, Novi gospodari svijeta i oni koji im se protive, Izvori, Zagreb, 2003. 
- Ziegler, JeAn, Imperij srama. Refeudalizacija svijeta, Izvori, Zagreb, 2007.

- ŽepIĆ, Božo, Enigma Bosna i Hercegovina, Logotip, Široki Brijeg, 2002. 


\section{SOCIAL INEQUALITIES AND POVERTY}

\section{Abstract}

We live in the period of high and fast technical and technological progress, in the period in which human destinies are burdened by new temptations and new challenges, period in which globalization process activities multiplied individuals and groups of people who were pushed from the center of social life to its margins. Poor and developing countries, where there are more and more people who live below the poverty lines, suffocating themselves by misery which leaves them hopeless and without human dignity, deal especially hard with the "new breakthroughs". Fortune and gains brought by new technologies are unequally distributed in the world. Spectacularly rich world was created from one side, and from the other side seriously impoverished world dominated by horrible poverty and deprivation. In that context the paper analyzes phenomenon of vertical social inequality, poverty and social exclusion with special overview of the Bosnian-Herzegovinian contemporary reality in which those phenomena are vivified.

Keywords: social stratification; social class; social stratum; poverty; social exclusion; Bosnia and Herzegovina 